brazilianpoliticalsciencereview

\title{
ARTICLE
}

\section{Brazilian Political Institutions: an Inconclusive Debate*}

\author{
Vicente Palermo \\ Consejo Nacional de Investigaciones Científicas y Técnicas, Argentina
}

The debate about the operation of Brazilian political institutions is far from conclusive. It could hardly be different, since current Brazilian democratic regime is only 30 years-old. This article updates a previous one, published in 2000, in which I discuss different and rival interpretations on the functioning of the Brazilian democracy. Some new works argue that a 'dialectic synthesis' of those strands has been recently produced. This article demonstrates this argument is not accurate. Instead, my main argument is that, in spite of rich analyses, new evidences and some displacements, the interpretations and paradigms guiding that debate remain the same. On the other hand, in spite of the solid position of the interpretation sustaining how the Brazilian political system ensures governability, the current institutional debate goes far beyond this paradigm by setting new themes and approaches. To demonstrate this argument, the article presents the evolution of such debate.

Keywords: Brazil; political institutions; Brazilian politics; governability.

B ack in 2000, I published an article in the Revista Dados, entitled "How is Brazil governed? The Debate about political institutions and management of the government", in which I presented a report on the debate among interpretative trends of the Brazilian political system. Instigated by the reactions to that report, and by the interest that it still raises, I give continuity in this article to that work, in the light of a handful of recent contributions.

(*) http://dx.doi.org/10.1590/1981-38212016000200003 
My main argument is that, although recent analyses about the Brazilian political system have introduced new evidence as well as have taken the discussion to new analytical dimensions, the interpretations and paradigms leading the debate remain the same. No matter how well established the paradigm asserting that the Brazilian political system ensures governability is, we assure that the debate about Brazil is moving far beyond. By the moment, we can say that it does so without breaking with old paradigms, but instead raising some new issues. This is the case of rethinking the notion of governability, perhaps very narrowly defined as the ability of the Executive to obtain, and hold, disciplined majorities in Parliament. Nowadays, the notion of governability also makes reference to good governance, and to the quality of public policy.

\section{Dialectic synthesis or parallelism of interpretations?}

Timothy Power (2010) argues that the debate about the operation of the Brazilian political system would have produced a 'dialectic synthesis', with the publication of Pereira and Melo (2014). In this section, I argue, in contrast, that it would be more accurate to say that there is new evidence indicating antagonistic interpretations about the conditions that explain the governability of the Brazilian political system.

Power (2010) wrote an article entirely dedicated to interpretations of the Brazilian political system over the time. The author distinguishes a first interpretation, pessimistic, and characterized by a diagnosis of ungovernability, that would have prevailed until middle 90s (AMES, 2001; LAMOUNIER, 1996; MAINWARING, 1999), from a second one, optimistic, in the sense of claiming that the institutions of the Brazilian political system are governable, and that would have become dominant at the end of that decade (AMORIM NETO, COX and MCCUBBINS, 2003; FIGUEIREDO and LIMONGI, 1999; PEREIRA and MUELLER, 2004; SANTOS, 2003), and from a third one, which, Power (2010) mentions, can be called coalitional presidentialism that "is somewhat of a 'grand unification' of earlier models, in the sense that it can accommodate insights from both the 'pessimists' and the 'optimists' at the same time" (POWER, 2010, p. 19). In that way, the author says: "the extensive literature about Brazilian political institutions can now be seen as assuming a rather clear dialectical form" (POWER, 2010, p. 19). 
As we can see, according to Power (2010), those paradigms have been successive over the time. In addition, there was an integration of them as the third paradigm would have incorporated elements of the previous two. It would be a dialectical movement in which the third paradigm would obviously be the synthesis.

Indeed, the three interpretations systematized by Power(2010) are currently discussing with one another ${ }^{1}$. Far from being considered in a diachronicdialectic sequence, they coexist today and do not involve a synthesis process. Although they emerged at different times, new interpretations did not replace previous ones. They remain, to a greater extent, more as live positions of a wideranging discussion, than as integrated components of a new interpretation. In reality, it is legitimate to wonder whether such an interpretation, new and synthetic, exists.

Certainly, the evidences underlying different positions change, but positions do not. Power (2010) mentions that "coalitional presidentialisms often used as a shorthand for the totality of ways in which macropolitics has adapted to the Constitution of 1988" (POWER, 2010, p. 26), but the notion of coalitional presidentialism, as a way of adaptation to the rules of the game is already considered by Abranches (1988). So, the Constitution of 1988 came after. Moreover, this 'totality of ways' is doubtfully a 'totality', in the sense that it can be seen as a cohesive understanding of the parts of the discussion in such a way that it integrates the different positions.

The first stage of the debate identified by Power (2010) is, as I said before, dominated by pessimism: it is a diagnosis of ungovernability. Barry Ames (2001) was probably - indicates Power (2010) - the most holistic of the critics of the Brazilian political system (POWER, 2010, p. 21). Armijo et al. (2006) also described in that way by arguing that: "the scholarly consensus suggests that a new democracy that is presidential, has centrifugal electoral rules (such as PR), and has extensive institutional separation of powers and purpose... should be particularly difficult to govern" (ARMIJO et al., 2006, p. 761). Bolivar Lamounier (1996) once characterized Brazil as subject to a 'hyperactive paralysis syndrome' (HP).

\footnotetext{
${ }^{1}$ As is the case, explicitly, of Palermo, 2000.
} 


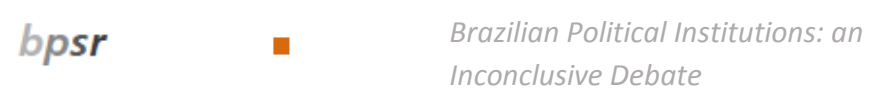

The crisis of this first interpretative paradigm emerged together with two processes. First, performances of government that clashed frontally with the interpretation of ungovernability were observed. Second, and somewhat later, the analysis of data about political process - as the discipline at the Chamber of Deputies -, also being inconsistent with this interpretation, forced to seek explanations that differed from those dominating until then.

Thus, the identification of game rules that had hitherto received poor attention, allowed setting up what Figueiredo and Limongi (1998) called the "institutional bases of coalitional presidentialism" (FIGUEIREDO and LIMONGI, 1998, p. 82). This type of presidentialism condensed, in the emergence of a new interpretation, a set of rules of solid explanatory power on the governance, that was perceived in the political system as a stronger presidential power in relation to the previous constitutions, or as a centralization of legislative production.

This rather optimistic interpretation has, as a central point, what has been described as executive dominance. The idea of executive dominance normalizes the Brazilian presidentialism, freeing it from pathological edges allocated by the first interpretative paradigm, and placing it in the more general category of presidentialist regimes tout court (thus, the concept of coalitional presidentialism remains strongly associated with this paradigm). Amorim Neto (2006) asserts that: "In a model of modern presidential government, the president is politically dominant in all the critical areas ... the new Brazilian democratic regime would be a clear example of a modern presidential government" (AMORIM NETO, 2006, p.320).

However, this characterization was soon softened by the central feature of Brazilian presidentialism, which is, establishing coalition governments. In coalition governments the executive loses unipersonal centrality. The distribution of decision-making power - and not so much of other material or symbolic goods, which also takes place - is relevant in Brazilian coalitional presidentialism. In this way, a double movement around the president takes place: on one hand, he uses the available institutional instruments to centralize decision-making but, on the other, he decentralizes it through the composition of the coalition cabinet.

According to Power (2010), a new phase in the evolution of interpretative paradigms is focused on party alliances, that is, the balances established between 
the parties of the governing coalition and their forces in Congress. But the attention on the behavior of these parties would not be of any importance, if it were not because it illustrates a point that must be highlighted: it reveals that similar interpretative positions have been debated over time. Examining the behavior of the parties belonging to the governing coalitions is just the other side of the coin of the persistence of problems identified by the first paradigm.

In fact, if you take into account the (relatively) stable and successful coalitions of Fernando Henrique and Lula, as mentioned by Power (2010), it can be seen that they used four tools: "continual adjustment of three variables (size, heterogeneity and proportionality of the support coalition in Congress), plus the use of pork (budgetary clientelism)"(POWER, 2010, p. 27). Now, each one of those tools serves a problem of 'ungovernability' identified by the first paradigm: either the extreme fragmentation of the political party system (hypothetically as a result of the proportional electoral system with open-list), or its lack of consistency, or the potential indiscipline at the Chamber of Deputies.

For the abovementioned, even if the concept of coalitional presidentialism assumed a 'dialectical form' "in the sense that it can accommodate insights from both the 'pessimists' and the 'optimists' at the same time" (POWER, 2010, p. 19), this dialectical form would not be completely comprehensive, as pessimistics and optimistics still maintain independent positions. The coexistence of an ungovernability diagnoses with a governability one was born at the beginning of 2000s and still prevails. Basically, the paradigm of executive dominance argues that the institutional variables of the decision-making process along with the institutional powers of the president act together as determinants of legislators' behavior in accordance with the preferences of political party leaders (ALSTON et al., 2011).

However, the identified sources of ungovernability remain in force, accompanied by concomitant diagnoses. For example, Armijo et al. (2006) should be included in the field of governability (but for different reasons from the dominant ones, as they understand that governability comes from the inexistence of veto powers and from the actors' obligation to engage in negotiations to avoid the risk of being excluded). Nevertheless, they observe that "Brazilian political institutions are decentralized and thus tend toward excessive resoluteness" 
(ARMIJO et al., 2006, p. 761), bringing back the diagnosis of ungovernability. As observed, there is not a synthesis, but the identification of problems, and the diagnoses about them coexist in tension within a broad debate.

\section{Imposing or organizing the cooperation?}

Among those admitting there is indeed governability in the Brazilian political system, there is a consensus. The system is turning around a pivot: the strong president. However, there are differences in the strategies used by the president to obtain parliamentary cooperation, considering that president and congress pursue different agendas.

The president is strong. But, what is he strong for? For imposing or for organizing cooperation? The paradigm of executive dominance supports the first. For Shugart and Carey (1992) strong presidents do not feel compelled to seek cooperation in congress. As they are strong, they impose their will; this would be the Brazilian case.

Note that Figueiredo and Limongi (1999) stand up for cooperation through dominance: "mechanisms to organize the agenda can increase the capacity of the President to seek cooperation, strengthening the cohesion of the governing base. A centralized decision-making process transfers the power to propose to the executive" (FIGUEIREDO and LIMONGI, 1999, p. 76).

An alternative interpretation maintains that cooperation is obtained through negotiations. Armijo et al. (2006), Palermo (2000), Pereira and Melo (2014, p. 35), say, differently from the imposition argument, that the Executive is able to organize political cooperation. According to Armijo et al. (2006):

\footnotetext{
...we identify the reasonably successful core of Brazil's framework of political institutions as its production of multiple incentives to all significant players to negotiate and cooperate. Each player retains some politically relevant resources, but no one, aside from (perhaps) the president, possesses actual veto power ( ARMIJO et al., 2006, p. 767).
}

Those incentives to negotiation come, largely, from the proactive tools of the president, as identified by the paradigm of Executive dominance, but especially from institutional balances between the actors, who are induced to cooperate. However, such dominance is less the result of the president's resources for 
imposing his agenda and relies much more on his ability to organize cooperation; in fact, the central point of this argument is the possibility of negotiation to ensure cooperation.

Hence, for some critical authors of the paradigm of the Executive dominance, this represents an excessive emphasis on formal rules, at the expense of analysis of political processes, in which actors have freedom to move between interests and institutions are more prevalent. This difference is, certainly, a landmark in the current political debate. Armijo et al. mentioned (2006): "(the recurrent model of negotiation) recognizes the same sources of inefficiency (ungovernability) than previous models did but, unlike the model of executive dominance, is skeptical about the ability of the executive chief to prevail for a long time through the harassment (bullying) of other politicians" (ARMIJO et al., 2006, p. 770).

There is no doubt the "driving forces of Brazilian policies is the set of strong powers given to the president by the Constitution of 1988" (POWER, 2010, p. 25). But his usage of available tools has allowed different interpretations.

\title{
Post consensus of governability?
}

But what is the scope of the analytical perspective that goes beyond governability? Although some displacements are clear, it does not seem that a consensus emerged.

Some authors call attention to the costs involved in obtaining governability. According to Armijo et al. (2006):

\begin{abstract}
Though time-consuming, constant negotiation performs the essential but sometimes underappreciated function of interest aggregation... the process of enabling multiple sectors and regions and interests to feel themselves to be participating in the national policy-making process is of utmost importance... Thus, a continuous debate between state governors and federal authorities over fiscal matters and allocation of funds... can be viewed as predatory federalism. Or it might instead be reconceptualized as a Brazilian version of checks and balances (ARMIJO et al., 2006, p.768).
\end{abstract}

Although the authors refer to incentives, it is evident that they place less emphasis on institutional rules, trying to connect the political system with society, 
and institutions with the social and economic Brazilian diversity. And they do so with a tinge of conformism, perhaps skepticism, by saying that the process could be seen as predatory federalism. In the same way, some authors would argue that the decision-making process is sufficiently, though not entirely, democratic. After the "path of muddling through gridlock" (KINGSTONE, 2000, p. 76), it would be an acceptable second best.

This spirit is largely expressive of a majority of authors which support the paradigm of governability. In their most schematic versions, as we have already pointed out, the notion of governability does not mean a good government.

Indeed, the interpretation that Brazilian political institutions ensure governability is stripped of important normative implications present in subsequent works. The wave of more recent contributions shifts the focus toward governance (PEREIRA and MELO, 2014), the quality of the political system representation (SANTOS and ALMEIDA, 2011), accountability, effectiveness and efficiency of public policies.

The contributions of Marta Arretche $(2009,2012)$ illustrate this point. Arretche (2012) argues that "incremental gains in state capacity to improve citizens' wellbeing were achieved in the last two decades" (ARRETCHE, 2012, p. 16). In other words, the author postulates a change in the quality of public policy, which is largely based on the decisions taken along the drafting of the 1988 Constitution (which does not mean that some of those do not indicate any problems of political legitimacy). The centralized logics of transfers toward municipalities, in a highly formalized process, with its impact on the reduction of cross-jurisdictions inequality, would be a good example. In this case, it is the capacity of the Brazilian political system to provide public services to citizens that is under examination.

This line of inquiry is not the only one of a sort of post-consensus about governability that seems to be assumed by the most recent literature. As Santos and Almeida (2011) indicate, proposals of reforms usually focus on governability, but a different concern should be raised: the enhancement of the political system must necessarily pass through measures that allow reducing the instruments of governability in the hands of the Executive, because the capacity of the Executive 
to intervene in the legislative agenda negatively affects parties. It would be a tradeoff with the representative dimension.

\section{Dysfunctions of coalitional presidentialism}

What are the inherent dysfunctions of coalitional presidentialism? It is assumed that it addresses and solves clearly identified dysfunctions. But, does it not produce other? Does the relevance of the use of material resources to organize the coalition not mean a source of misrule? Pereira and Melo (2014) largely express the ambiguity with which coalitional presidentialism is perceived:

...it can be considered as a suboptimal functional settlement. It can be plenty of many problems, including clientelism, corruption and lack of transparency. The extensive use of pork and other political currencies can undermine the legitimacy and represent a downside of this method of government. However, it has generated political stability and has not degenerated into systemic corruption, with robust political competition and strong autonomous institutions (PEREIRA and MELO, 2014, p. 175).

Has it not degenerated into systemic corruption? In any case, to what extent the dynamics of corruption scandals is not rooted in the mechanisms of the presidential management of multiparty coalitions?

Amorim Neto (2006) also believes that the emergence of Executives supported by stable majorities at the Congress, and of a solid division between government and opposition, occurs at the high price of excessively debilitating the Legislature and the representatives, considered individually.

Figueiredo and Limongi (1999), in turn, argue that the presidents of the current democratic era proved to be more effective than those of the period 19461964 in the pursuit of their programmatic agenda. However, this would have happened in detriment of representatives' participation in the drafting of laws, specifically in those areas in which the Executive has exclusive legislative initiative. The improvement of government effectiveness took place at the cost of establishing a zero-sum game between the President and representatives. The change of parties systematically carried out by legislators can be seen as an instrument of governability, but also, as a focus of delegitimization of the Congress and of political parties. The same can be said about the integration of the cabinet as 
an instrument of coalitional composition; for example, the ministerial cabinet of Dilma reached 39 members. Beyond the cost of coordination, it is clear that this affects the intrinsic quality of public policies. Meanwhile, the number of effective parties in the new legislature is thirteen (number that was never reached before), and the biggest party barely reaches $13 \%$ of the members, a degree of fragmentation that contradicts many diagnoses about the evolution of the party system, and that might block the formation of stable majorities.

Power (2010) considers that "the enhancement of presidential agenda power (to achieve governability) implies a reactive legislature (which may erode democratic quality)" (POWER, 2010, p. 27). The coalitional presidentialism has gone from being described as a 'dilemma' (ABRANCHES, 1988) to being understood as 'ordinary politics' (ZUCCO JR., 2007). Actually, for him, it continues to be a dilemma, considering that the option itself implies costs. Its interpretative 'standardization' does not impede from perceiving its problematic dimensions.

In contrast, Pereira and Melo (2014) indicate that although "these exchanges are often viewed as less than legitimate by the press and the majority of society, they constitute the basis of relations between the executive and legislative powers in Brazil ... such exchanges lead to high levels of governability allowing us to carry out important reforms"(PEREIRA and MELO, 2014, p. 176). Hence, the operation of coalitional machine involves the creation of permanent gaps between society and the political system, so that the exchanges are as necessary as costly in terms of legitimacy.

Therefore, the relation between corruption and governability is a central point. In the current Brazilian political system, taking into account their rules of game, can we say that corruption is inherent to governability? In other words, the system does not work without an ingredient of corruption, as it is often a requirement for building alliances. But if so, the corruption is by itself a source of ungovernability (as it is illustrated by the case of mensalão, but also by some aspects of the representation crisis, because the corruption is one of the reasons that explain the rejection of political parties and politicians). In sum, corruption, which is necessary for good governance (at least under the coalitional presidentialism), is at the same time a disruptive factor of ungovernability. 


\section{Governability, centralization of decisions and interests}

A problem related to the preceding one is the funding of political activities, which is one of the negative aspects that also helps to deepen the representation crisis and the gap between the political system and the citizenship. As observed by Samuels (2006) "the interests of corporate elites influence elections and political process... the presidential dispute is almost entirely funded by companies' contributions... key point, the absence of national influence of parties on the distribution of funds of campaigns" (SAMUELS, 2006, p. 145). This close proximity between corporate elites and political candidates weakens the parties, as well as undermines their legitimacy, as the electorate perceives the relationship between politics and business as negative.

Indeed, the nature of the relation between the political system and corporate interests is at stake. The 'capitalism of ties' (LAZZARINI, 2011), as a form of representation of economic agents in Brazil, is highly asymmetric, tilted in favor of the latter. It is inscribed in the current 'political grammar' (NUNES, 2010), even because of the numerical importance of entrepreneurs in the parliamentary blocs. The institutions of coalitional presidentialism, starting with electoral rules, have been able to do very little to soften this imbalance. So, we have a 'capitalism of friends' with a bifront shape, meaning that it combines a sector closer to a typical 'crony capitalism', and another one chaired by highly institutionalized forms - a 'capitalism of ties'.

In one way or another, these configurations were set in motion by the reforming coalition under the command of Fernando Henrique Cardoso. As Lazzarini (2011) mentions, "nothing more natural than involving public or private actors, already enmeshed in local networks, in the process of economy restructuration" (LAZZARINI, 2011, p. 114). It is important to clarify that state institutions often dominate the game, taking precedence over capitalists (even if it is to serve them better, following Francisco de Oliveira et al. (2010), and that the parties are the ones which result oppressed by these tensions. "Pension Funds Fernando Henrique Cardoso, said - are "new stars"... With a little help of BNDES bank, then, everything is perfect: we have the alliance between State, trade unions, pension funds and the luckiest large companies who benefit from associating with them" (cited by LAZZARINI, 2011, p.116). "Pension funds of state companies - 
adds Lazzarini (2011) - were and probably will be political instruments of the government - any government" (LAZZARINI, 2011, p.116).

The main point here is the power concentration of the political system. The decision-making centralization in the Executive and in specialized institutions, such as the BNDES, implies narrowing access and spaces for influence which improves governance but also makes more opaque and selective the 'intimate and historic entanglement' from which political actors are, in the long run, excluded.

Meanwhile, a breakthrough, involving both the different levels of the state and the political forces, has been the insulation of certain public policies - mainly, education, health, income transfer - from the exchanging of political favors.

It should be noted that the revaluation of the representative dimension takes place in Brazil, after undergoing some major changes in the relationship between society and the political system that, in contrast, represents a remarkable continuity. In effect, while the protests of June 2013 showed how the renewal of Brazilian democracy has as a source a critical public opinion developed outside institutions $^{2}$, the presidential elections, with PSDB and PT reaching the second round, shows that the party system continues its course, reinforcing the bipartisan pattern of the presidential competition (in spite of increasing fragmentation at the state level). Although it is too early to see it, the improvement of Brazilian institutions could be obtained both from the institutional game and from an active public opinion. The perception of corruption, for example, emerges strongly and, without any doubt, will have an impact in the future. The Law of Clean Tab (Lei da Ficha Limpa) is a result of these on-going changes ${ }^{3}$.

It is true, as Pereira and Melo (2014) argue, that people have shown higher levels of confidence in the judiciary and the media: "this level of expanded accountability has clearly led to a great citizen dissatisfaction with the status quo ... Brazil is in transition toward a good governance, and improved effectiveness of checks has resulted in an expanded consciousness on political corruption" (PEREIRA and MELO, 2014, p. 136). But here the explanatory variable effectiveness of checks - receives the full weight of the explanation, which is a little difficult to sustain. Besides, greater levels of confidence in the judiciary should not

2 Only 25\% of young people, between 16 and 17 years old, obtain the elector title; this number is dropping since 2006.

${ }^{3}$ I thank Helcimara Telles for the ideas exchanged about these issues. 
be exaggerated as well as the causal relationship attributed to citizen dissatisfaction could be taken more cautiously (if we have in mind, for example, the impact of judicial 'delays' in the mensalão). In fact, other factors seem to be more important, such as increasing social expectations due to economic progress or dissatisfaction with the high levels of the tax burden along with citizens' perceptions regarding the underfunding of first-order public policies.

\section{Leadership styles and strategies: do they count?}

The authors who assign (almost) all explanatory power to institutional rules (as Figueiredo and Limongi (1998), for example), assume that the quality or the nature of leadership is not decisive to explain the performance of government coalitions. An evidence to support this argument would be that good performance cannot come from very dissimilar leadership styles. This is a dimension where authors attributing the Executive dominance to the rules of the game seem to go too far.

Contrastingly, those authors who deposit part of the explanation in the interactions of actors having capacity of choice (as ARMIJO et al., 2006; PALERMO, 2000), give the leadership (and differences in style, talent, abilities of persuasion, experience, good fortune, etc) a much greater explanatory role. The choices of leaders, for them, are conditioned but not determined by game rules. They depend on interpretations, not only on changing conjunctures, of the political-institutional morphology in which they are developed (because rules are 'read' in different ways).

For sure, institutional constraints have an undeniable role. It can be said, for example, that Lula made political errors in his first term, when building his government coalition; learning from these mistakes, in turn, provided for later emendation in the configuration of a more consistent and stable coalition in his second term. This enables us to conclude that some readings are more adequate than others; but never that leaders are fiercely subject to rules. As highlighted by Amorim Neto et al. (2003), "the pattern of governability in Brazil depends on a strategic choice made by the president according to the specific policy conditions that he faces" (AMORIM NETO et al., 2003, p. 568). This strategic choice happens between two governmental formulas: multiparty majoritarian governments (or 


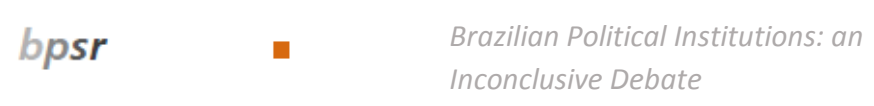

multiparty cartel) and multiparty minority governments (or absence of cartel). This strategic choice is fully political and is not mechanically a by-product of any institutional morphology.

\section{Checks and balances: from governability to good government}

In spite of the governability paradigm being firmly rooted, we can be sure that the Brazilian political debate is going much further. Now, the notion of governability also includes the good government and the quality of public policies. Perhaps Pereira and Melo (2014) are emblematic of this position. They argue that a good government depends not only on a (institutionally) strong president, but also, on an institutional network of checks and balances that counterweigh the presidential power. For them, Brazil has done very significant advances in these areas since the Constitution of 1988. In other words, for the authors, Brazil is not only a governable country, but a country susceptible to be well-governed. This possibility rests on the operational effectiveness of several institutions (extensive controls by the Congress, judiciary, state governors, Public Ministry, audit agencies, etc). Hence, the governability sources would be different from those advanced by the interpretation stressing the executive dominance.

A shift in the problem of investigation from governability to good government involves devoting more attention to control institutions and to balances and checks of the political system. It is assumed that, in a presidential system, it is these institutions which prevent degeneration. They, in fact, constrict political actors to be bound by the law. The judiciary constitutes part of the checks and balances system, and so the quality of its operation directly affects the possibility of good governance.

The good performance of Brazilian judicial institutions and audit agents (according to international comparisons), depends on political competition. As indicated by Pereira and Melo (2014), elite competition and political fragmentation increase the costs of coordination of political elites and make it more difficult to attack the judiciary and to control the institutions after decisions affecting their interests are made; thus, the more competitive the political system is, the more autonomous judicial institutions and audit agents are. 
This interpretation represents a point of view fairly novel concerning the proverbial fragmentation of the Brazilian party system. Given that Pereira and Melo (2014) argue that the political competition and the diversity of political parties operate to restrict presidential action, we can infer that reducing the number of parties would be actually counter-productive, potentially increasing the executive dominance.

\section{Displacements in the agenda}

\section{From presidentialism to political institutions}

Ex post facto, it is clear that the 1988 Constitution framers made a strategic decision: instead of reframing the most problematic aspects of the Brazilian political-institutional framework, they basically led them intact and put in place instruments aiming at counteracting its effects. This strategy is not novel in the drafting of constitutions; but in this case, it is particularly striking how clear it was. That is the case of some proactive instruments allowing the president to both keep the initiative in the political agenda and organize the cooperation of a large number of parties. Actually, it is the institutional powers upon which relies the legislative work and the president actions which makes inconsistent organizations to turn into political parties with discipline and cohesion. This might be an artificial consistency, but it is effective, considering that the parties gain stability and predictability. The statement that 'political parties matter' despite the fact they are still weak and fragmented organizations (NICOLAU, 2015), typical of the governability paradigm, opens the path toward the understanding of the ways in which the decision-making power in the Brazilian coalitional presidentialism is distributed.

First, the executive power is shared (AMORIM NETO, 2000; PALERMO, 2000). This is a pre-condition for the existence of a government coalition. Depending on the case (coalescence), this distribution expresses the partisan diversity of the coalition, mediated by the number of seats each party has in Congress. It also introduces a strong element of consensualism in the political dynamics. All that has been observed contradicts the notion, assumed by the ungovernability paradigm, that under presidentialism it is impossible to share the 
executive power or to structure effective inter-party coalitions. On the contrary, the dynamics of coalition formation and its role on the effectiveness of presidential regimes has displaced the electoral rules as the center of the debate.

Presidents, using their institutional agenda powers, can build coalitions, or to be more exact, transform initially minority governments into majority ones (SANTOS, 2003). Of course, stable coalitions in Brazil would be impossible without centralization instruments; the same can nonetheless be said about decentralization forces, as once the political parties hold ministerial positions, their preferences matter, even if the initiative in the decision-making process is kept in president's hands. Actually, it is not a zero-sum game; the president gains power, and so do political parties. The first is strengthened by centralizing the decision-making power and by having a majority and more reliable supporting political forces; the latter by sharing the cabinet. According to Amorim Neto (2006), the fact that "almost all of the presidents that did not obtain or maintain a parliamentary majority, did not complete either their constitutional mandates" (AMORIM NETO, 2006, p. 342), indicates that although the president figure is powerful, the parliamentary base is essential.

One might think that the presidential predominance is in part a consequence of both weakness and poor consistency of political parties: political parties do not fulfill their role of bringing near what is different, overcoming the dissimilarity of purposes. Then, presidents make it directly (in this sense, there is a significant difference with parliamentarism), by dominating the parliamentary agenda, a process in which political parties acquire a different consistency.

The truth is that, if after three decades of debate, presidentialism is not being blamed anymore, new elements are being introduced into the discussion, related to: the role of the fragmented partisan system as a counterbalance to the presidency power; the key importance of checks and balances for good government; and the ways in which presidents build and hold coalitions.

\section{Congress as an active actor}

Better understanding the role of Congress is a new field of study that diverges from the executive dominance paradigm. A recent example is the book written by Santos and Almeida (2011), studying how legislators overcome 
institutional barriers to acquire and distribute information related to the framing of public policies. By arguing that the Brazilian coalitional presidentialism has clear informational foundations, the study breaks with the previous consensus, which assigned to the Committees a passive role. Instead, authors argue that the system of permanent committees has a relevant informational role, and not just the reactive role that literature recognizes. Committees have the capacity to produce additional information to what is produced by the Executive, reducing the uncertainty of the floor. The production of their own and more reliable information is valuable when voting projects.

Thus, Santos and Almeida (2011) mention: "A new generation of studies about Congress is pointing out several features of legislative activity that mitigate the classification of Senate as reactive... Studies about specific public policies also indicate a more proactive behavior..." (SANTOS and ALMEIDA, 2011, p. 128) 4 .

Another example is the important article of Silveira and Silva (2014) about the 'appropriation' phenomenon, by which presidents take as theirs, bills being proposed by Congress. The authors mention, "Appropriation shows that Brazilian Presidents must go beyond coalitional presidentialism" (SILVEIRA and SILVA, 2014 , p. 126). The appropriation would make it clear that the president's agenda power is also used in different ways than those provided by the executive dominance paradigm:

...partisan and ideological diversity as well as the multitude of topics up for debate in Congress do not always make formal majorities as malleable as the President's need to govern... agenda power may be applied to the articulation of new expressions for forming parliamentary majorities, both for the strengthening of formal coalitions as well as for the construction of majorities, also external to the party base of government support. And this is the new way of looking at the power of the agenda as indicated by the practice of Appropriation. (...) the perspective of the phenomenon of Appropriation points to an alternative use of the agenda power that does not present as much adhesion to formal coalitions, which ground many of the arguments on coalitional Presidentialism" ( SILVEIRA and SILVA, 2014, p. 122).

4 These authors refer to: Amaral, Ana Regina Villar Peres (2009); Braga, Ricardo de João (2011); Gomes, Fabio de Barros Correia (2011); Martins, Ricardo Chaves de Rezende (2011); Souza, João Ricardo Carvalho de (2010) and Vieira, Fernando Sabóia (2009). 
The formation of coalitions ad hoc, with participation of the opposition, is typical when this instrument is in the hands of the Executive. In sum, appropriation would aim to compensate the high political costs for the president, inherent to holding together a very heterogeneous formal coalition.

\section{Strengthening representation}

Some studies have highlighted some facets of the Brazilian political representation that, at least, make it mandatory to soften the tone of usual interpretations, pointing out its serious deficits. That is the case of two excellent articles, by Gurza Lavalle et al. (2006), and by Pogrebinschi and Santos (2011). The first examines processes that, involving the Executive, reconfigure conventional representation and can converge toward a new expansion of democracy. Their study essentially examines the political representation exerted by civil organizations. Backed by a solid empirical research, Gurza Lavalle et al. (2006) point out that:

The support supplied by civil organizations to political candidates is, by far, the more accurate prediction variable for the propensity of these civil organizations to assume the representation of their beneficiaries. Other factors also point to the centrality of the interrelations between civil organizations and political institutions... dynamics of political representation in the field of civilian organizations does not occur in parallel or alternative to traditional channels of politics, but in close connection with them... as an effort of intermediation to establish connection between segments of population, bad or underrepresented, with the State and the circuits of electoral politics (GURZA LAVALLE et al., 2006, p. 44).

The authors also indicate a 'relevant historical displacement' in the meanings the organizations themselves confer to their actions. Thus, the typical forms of representation prevailing in the second half of the XXth century, such as the criticism of political representation and the notion of 'genuine representation', gave way to "new understandings clearly embodying the processes of reconfiguration of political representation by extending its locus and functions to the field of drawing, implementing and supervising public policies" (GURZA LAVALLE et al., 2006, p. 55). This reconfiguration process would have taken place with the support of long-term changes in civil organizations profiles, which 
occurred in the framework of the transformations of the Brazilian state in the last few decades.

Meanwhile, Pogrebinschi and Santos (2011) frame their research in some broader debates contrasting, within the democratic theory, variables of participation, discussion and representation, and the Brazilian specifics. Analyzing the impact of deliberations of national conferences on public policies over the legislative activity in Congress between 1988 and 2009, the authors conclude that "mechanisms that seek to expand the participation of citizens in the political decision-making process can impact the legislative production of the Brazilian Legislative Power" (POGREBINSCHI and SANTOS, 2011, p. 260). In this way, an empirical investigation of considerable scale allows them to understand on the one hand, how processes of participatory and deliberative nature are articulated with the representation process, as new forms of political mediation that present strong potential to deepen democracy in Brazil:

We are interested in facing the national conferences of public policies as participative experiences that, in the meantime, strengthen the formal political representation and reinforce the functions and activities of traditional political institutions... national conferences strengthen parliamentary representation multiplying the ways of vocalization and aggregation of important interests for society. In this sense, conferences provide a new form of expression of participatory elements that constitutes the concept and practice of political representation (POGREBINSCHI and SANTOS, 2011, p. 299).

On the other hand, establishing these characteristics on an empirical basis makes it possible to foray into the field of democratic theory, arguing that "participation and resolution can be taken as constituent elements of political representation" (POGREBINSCHI and SANTOS, 2011, p. 300). The data collected

...seem to contribute to deconstruct the discourse that representative democracy and its institutions are in crisis in Brazil, as well as the argument that political representation is a second best alternative, considering the factual impossibility of establishing, in contemporary societies, direct forms of democracy that provide the participation of citizens without the mediation of elected representatives (...) social participation should not be understood as the opposite to political representation (POGREBINSCHI and SANTOS, 2011, p. 300). 


\section{Political culture}

Power (2010) mentions "Coalitional presidentialism has a far better 'fit' with reality after 1995, during the Cardoso-Lula era, than it did in the comparatively chaotic early years of democracy. We cannot yet be sure why this is the case" (POWER, 2010, p. 29). A possible interpretation is that there was learning based on the experiences with institutional rules, and that this learning resulted in effective courses of action when virtuous leadership emerged. As observed by Whitehead (2009), FHC presided the transition toward mass politics. With the arrival of PT, the transition was completed. Not only because, beyond the fluctuation of voters, large segments of electorate were included in an unprecedented way in democratic politics, but also, because a new elite came to power completing the spectrum of political representation ${ }^{5}$ (POWER, 2010, p. 62).

However, one of the reasons why coalitional presidentialism settled with Cardoso and Lula is the harmony between the set of rules and the Brazilian political culture. This can be defined as the culture of composition, which appreciates pragmatism and negotiation, while being akin to cooptation and elitist conciliation. It does not give many chances to the emergence of populist leaders, making leadership a rather institutional element (as evidenced by the trajectory of Lula's leadership, before and after his arrival to the Presidency). It also delimits a fuzzy line between public and private sectors, and does not defend the government from the rule of law. Additionally, it presents "disturbingly low levels of attitudinal support for democracy" (POWER, 2010, p. 30). In the operation of the Brazilian political system, these characteristics are present as both normative rules and practices. The President exercises a leadership of composition, avoiding to establishing direct links with public opinion, and systematically practicing cooptation of individuals, and especially, of collective actors (Lula is not an exception to this). Political elites consummate endless transactions and a myriad of clients seek to outflank, permanently, the limits of the public.

\footnotetext{
${ }^{5}$ As observed by Santos (2008) "what appears to be the most important variable in the stabilization and rationalization of the political game in Brazil is the emergence of a strong leftist party, both at the ballot box and in Congress, whose leaders are focused on occupying government with the aim of promoting changes to the status quo, within the context of the rules of representative democracy" (SANTOS, 2008, p. 63).
} 
Hence, the political culture of Brazilian people (ALMEIDA, 2007), favors an approximation to the manners of society (the Brazilian 'jeitinho), accepting the corruption and also the flexibility with which the political system deals with it. Great part of society rejects in politics what at the same time is willing to accept in its own political culture. Of course, this is a widespread phenomenon and, in Brazil, as in other places, contributes to deepen the existent gap between society and political system. As mentioned by Pereira and Melo (2014), protests have been against government performance, not against institutions. It could hardly be otherwise, but this feature shows the virtuous effect of preserving the institutions from the fury that chooses men as a target.

\section{Political reform}

The debate about a reform to political institutions has been permanent and has been translated in different bills. Some authors, including Santos (2006), have begun to discuss proposals for strengthening the legislative branch. But it is obvious that this discussion is characterized by incrementalism and caution. Soares and Rennó (2006) mention that along with several proposals for specific adjustments, there is strong resistance to drastic change of the Brazilian politicalinstitutional structure. In other words, Brazil continues with its tradition of partial reforms; only in part, this is related to the uncertainty arising, among potentially affected people, from a change in the rules of the game. It also relates to a spirit of conservatism that is wary of institutional innovation.

As Soares and Rennó (2006) have mentioned, some people support the idea of maintaining the actual structure of political representation, because by doing so, they consider, the system would go toward stable and desirable results. For others, in contrast, the Brazilian electing system creates some distortions in the links between elected representatives and voters. They suggest a reduction in the number of candidates and in the magnitude of districts, and the adoption of closed-lists, and, above all, the prohibition of coalitions in proportional elections (NICOLAU, 2015). These changes would tend to provide more visibility to voters and more ability to evaluate representatives, as well as would forge closer ties with political parties. 
Anyway, the care to highlight the pros and cons of each alternative, and to note that each problem is inevitably a dilemmatic one, is permanently present. As seen in Nicolau (2006), who examines the closed-list, open and flexible systems, whatever the chosen system is, there will always be inevitable advantages and disadvantages when 'buying the package' (negative aspects along with positive ones). The issue is closely related to the trade-off 'representation-governability'.

Of course, the political reform is more important for those who perceive the Brazilian political system going through a deficit of representation. In this case, some audacious suggestions have recently been created (SANTOS and ALMEIDA, 2011), specially related to reforms oriented to giving a more active role to the legislative power. The objective is to increase the benefits of being in the opposition and to decrease the costs of being outside the government. The change would focus on the rules of Congress organization benefiting the parliamentarian of the opposition and reducing the costs of not having position in the cabinet. The idea is to: increase the Congress' power to allocate resources (making the budget imperative instead of authoritative); increase the decision-making power of permanent technical committees; and, alter the structure of the opportunities that politicians face.

However, we might wonder whether these reforms would fit in the logic of coalitional presidentialism or would break with it. Would a congress with more ability to allocate resources and with a greater decision-making power in its permanent technical Committees, not be separate from the golden rule of coalitional presidentialism, which is the dominant role of the president as center and coordinator of the political cooperation and as great formulator of initiatives? Perhaps, if adopted, proposals such as the aforementioned would usher in a stage that will leave behind coalitional presidentialism as we know it today. They would open a space of uncertainty, but would mean the promise of a new improvement for the Brazilian democratic quality.

\section{Final questions}

Taking into account the discussions conducted so far, we believe appropriate to ask two questions, yet we cannot give definitive answers to them. 
The first one is: Does the Brazilian political system have the essential conditions to preserve itself from (semi)authoritarian experiences, particularly those that have been recently seen in Latin America, where a political force with anti-republican (and anti-liberal) characteristics reaches the government and consolidates a dominant electoral position (temporarily), and is supported by a long enough period of fiscal and external bonanza? If we observed, for example, the case of Argentina, the answer would be clearly negative. In Brazil, the answer to the paradigm of governability would be ambiguous: it is impossible to obtain a clear conclusion in this regard. In contrast, Pereira and Melo (2014) would give an affirmative answer: the Brazilian political system counts with auto-defenses, particularly related to its checks and balances. The PT may have unbalanced the political system; its behavior was sparsely republican in many fields, and it even made attempts to consolidate a position of power bowing rules of the game, but did not succeed to alter the political system (aparelhamento do estado, media regulation, etc).

However, the question considered as a whole, I think, was not the case of such an overflow. Why is that? On the one hand, the structure of the Brazilian political party system is very fragmented and competitive, which made the PT not being able to achieve a dominant position. On the other hand, the strength of controls (a strong presidency counterbalanced by control institutions that work) would prevent authoritarian strategies. Moreover, perhaps, a different historical orientation in political/cultural level, made the difference: while in Argentina this orientation would be in favor of the dominant parties or the hegemonic movements, in Brazil the post-varguista configuration that emerged in 1946 gave rise to a multiparty array, and to subsequent electoral bases that were maintained. Finally, the density of social actors, and their strength vis à vis state and political actors, demonstrates the existence (relatively recent) of a civil society independent from the state ${ }^{7}$.

The second question is: considering the conditions to preserve itself from authoritarian experiences, does Brazil also have the conditions to preside sustained economic growth and prosperity, as Acemoglu and Robinson (2012), and more recently, neoinstitutionalist approach argue, based on the role of correct incentives emerging fundamentally from political-institutional frameworks? The 
answer is more doubtful. Alston et al. (2011) would be optimistic, answering yes with caveats. Pereira and Melo (2014) would also be included in this group. In these cases, the argument would be that Brazil walks slowly but firmly toward the rule of law; the consolidation of republican institutions; the division of powers; and, everything that would be, as property rights, the pillar of limited power and of the reduction of transaction costs; briefly, basic incentives and strategic blunders of growing and prosperity.

Assuming that this theory is correct, it must be remembered that Brazil has a long tradition of state intervention, which is not consonant with the institutionalist prescription. In any case, the harmonization of both grammars is yet to be seen (although we are talking about a country that, according to Nunes (2010), has always been able to harmonize different grammars). Anyway, what seems to be clear is that the Brazilian political system is not in its way to redefine the relationship between the state and the world of economic agents. In other words, it is not so clear that Brazil is going to 'correctly' set incentives.

\section{Conclusions}

Considered in its broadest terms, the Brazilian debate on political institutions seems to evoke, in the best Brazilian intellectual tradition, the balance of opposites (FREYRE, 2007). The debate perceives the political system as a set of rules and incentives, in opposition, not in synthesis, but in an unstable equilibrium, in which each rule produce effects, and generate contrary incentives. To give a simple example, the electoral rules provide incentives for politicians behaving individually, while the internal rules of Congress, the president's power to legislate, and the centralization of benefits by the president, create incentives for legislators to be loyalty to their political party and to the presidential preferences. Even when this balance of opposites is not unique to Brazil, it is strongly rooted in historical processes of the Brazilian national policy. It is, in a way, the touchstone of the Brazilian political institutions. The most recent development of mechanisms of checks and balances (PEREIRA and MELO, 2014) is part of this line of institutional development.

Based on this perspective, the reason why the interpretations about the Brazilian political system are so dissimilar gets clear. As Amorim Neto (2006) 
observes, while Figueiredo and Limongi (1999) say the actual Brazilian system operates similar to the parliamentarian system (political parties as coordination mechanisms), Ames (2001) asserts the opposite: political parties are brought to govern through fragile ad hoc coalitions. For Amorim Neto (2006), however, the pattern of governability is neither consistently atomistic nor consistently parliamentarian. Considering the governments of Sarney, Collor, Franco, and FHC, "only the latter formed a solid multi-party cabinet and controlled legislative agenda as an European prime minister. The others did so through unstable ad hoc coalitions" (AMORIM NETO, 2006, p. 344).

The fact is that the Brazilian political system has demonstrated all these years a remarkably stability (another reason to be careful in the proposition of changes). It is not entirely clear which reforms to get rid of the danger of 'unstable coalitions ad hoc' or of cesarists experiences would be. Anyway, it is noticeable that, even if now the interpretations about the Brazilian political system can be different, these are not as comprehensive as when the debate was polarized between only two paradigms. The opening of a very expressive research space beyond the consensus of governability is a significant promise for the Brazilian academic debate.

Translated by Cabo Verde Submitted in October 2014 Accepted in August 2015

\section{References}

ABRANCHES, Sérgio (1988), Presidencialismo de coalizão: o dilema institucional brasileiro. Dados - Revista de Ciências Sociais. Vol. 31, № 01, pp. 05-34.

ACEMOGLU, Daron and ROBINSON, James A. (2012), Why nations fail: the origins of power, prosperity and, poverty. New York: Crown Business. 529pp.

ALMEIDA, Alberto (2007), A cabeça do brasileiro. Rio de Janeiro: Record. 280pp.

ALSTON, Lee J.; MELO, Marcus André; MUELLER, Bernardo and PEREIRA, Carlos (2011), En el camino hacia un buen gobierno: recuperación de impactos económicos y políticos en Brasil. In: El juego político en América Latina, ¿cómo se deciden las políticas públicas? Edited by SCARTASCINI, Carlos; SPILLER, Pablo; STEIN, Ernesto and TOMMASI, Mariano. Washington: Banco Interamericano de Desarrollo. pp. 117-160. 
AMARAL, Ana Regina Villar Peres (2009), The Brazilian parliament - process, production and legislative organization: the role of committees in a comparative perspective. Master's Dissertation. Rio de Janeiro: IUPERJ.

AMES, B. (2001), The deadlock of democracy in Brazil. Ann Arbor: University of Michigan Press. 352pp.

AMORIM NETO, Octávio (2006), A reforma do sistema de governo: rumo ao parlamentarismo ou ao semipresidencialismo? In: Reforma política: lições da história recente. Edited by SOARES, Gláucio A. Dillon and RENNÓ, Lucio R.. Rio de Janeiro: FGV Editora. pp. 316-344.

AMORIM NETO, Octávio (2006), El presidentialismo moderno en Brasil. In: presidencialismo y parlamentarismo: América latina y Europa Meridional. Madrid: Centro de Estudios Políticos e Constitucionales. pp. 103-132.

AMORIM NETO, Octávio (2000), Presidential cabinets, electoral cycles, and coalition discipline in Brazil. Dados. Vol. 43, № 03, pp. 479-519.

AMORIM NETO, O.; COX, G. D. and MCCUBBINS, M. D. (2003), Agenda power in Brazil's Câmara dos Deputados, 1989 to 1998. World Politics. Vol. 55, № 04, pp. 550-578.

ARMIJO, L.; FAUCHER, P. and DEMBINSKA, M. (2006), Compared to what? Assessing Brazil's political institutions. Comparative Political Studies. Vol. 39, № 06, pp. 759-786.

ARRETCHE, Marta (2009), Continuidades e descontinuidades da federação brasileira: de como 1988 facilitou 1995. Dados - Revista de Ciências Sociais. Vol. 52, № 02, pp. 377-423.

ARRETCHE, Marta (2012), State effectiveness in contemporary Brazil. LASA FORUM. Vol. 43, № 04, pp. 15-17.

BRAGA, Ricardo de João (2011), The legislative decision-making process in the creation and reform of Bacen and of CMN in 1964 and in 1994: uncertainty, cooperation and legislative results. PhD Thesis. Rio de Janeiro: IESP-UERJ.

FIGUEIREDO, A. and LIMONGI, F. (1999), Executivo e legislativo na nova ordem constitucional. Rio de Janeiro: Editora FGV. 232pp.

FIGUEIREDO, Argelina and LIMONGI, Fernando (1998), Bases institucionais do presidencialismo de coalizão. Lua Nova: Revista de Cultura e Política. № 44, pp.81-106.

FREYRE, Gilberto (2007), Casa grande \& senzala. Formação da família brasileira sob o regime da economia patriarcal. São Paulo: Global Editora. 703pp. 
GOMES, Fabio de Barros Correia (2011), Interactions between the legislative and the Brazilian federal executive in the definition of broader interest policies: a systemic approach, with impact in health. PhD Thesis. Rio de Janeiro: IESPUERJ.

GURZA LAVALLE, Adrián; HOUTZAGER, Peter and CASTELLO, Graziela (2006), Representação política e organizações civis. Novas instâncias de mediação e os desafios da legitimidade. Revista Brasileira de Ciência Sociais. Vol. 21, № 60.

KINGSTONE, P. R. (2000), Muddling through gridlock: economic policy performance, business responses, and democratic sustainability. In: Democratic Brazil: actors, institutions and processes. Edited by KINGSTONE, P. R. and POWER, T. J.. Pittsburgh: University of Pittsburgh Press. pp. 120-147.

LAMOUNIER, B. (1996), Brazil: The hyperactive paralysis syndrome. In: Constructing democratic governance: Latin America and the Caribbean in the 1990s. Edited by DOMINGUEZ, J. I. and LOWENTHAL, A. Baltimore: John Hopkins University Press. pp. 176-210.

LAZZARINI, Sérgio (2011), Capitalismo de laços: os donos do Brasil e suas conexões. Rio de Janeiro: Editora Campus. 208pp.

MAINWARING, S. (1999), Rethinking party systems in the third wave of democratization: the case of Brazil. Stanford: Stanford University Press. 412pp.

MARTINS, Ricardo Chaves de Rezende (2011), The legislative power and public educational policies in the period 1995-2010. PhD Thesis. Rio de Janeiro: IESPUERJ.

NUNES, Edson de Oliveira (2010), A gramática política do Brasil: clientelismo, corporativismo e insulamento burocrático. Rio de Janeiro: Garamond Universitaria. 196pp.

NICOLAU, Jairo (2006), Voto personalizado e reforma eleitoral no Brasil. In: Reforma política: lições da história recente. Edited by SOARES, Gláucio A. Dillon and RENNÓ, Lucio R. Rio de Janeiro: FGV Editora. pp. 23-33.

NICOLAU, Jairo (2015), Uma proposta de reforma do sistema eleitoral brasileiro. Revista Cadernos de Estudos Sociais e Políticos. Vol. 04, № 07, pp.

OLIVEIRA, Francisco; BRAGA, Ruy and RIZEK, CIBELE (eds.) (2010), Hegemonia às avessas: economia, política e cultura na era da servidão financeira. São Paulo: Ed. Boitempo. 400 pp.

PALERMO, Vicente (2000), Como se governa o Brasil? O debate sobre instituições políticas e gestão de governo. Dados - Revista de Ciências Sociais. Vol. 43, № 03, pp. 521-557. 
PEREIRA, C. and MUELLER, M. (2004), The cost of governing: strategic behaviour of the president and legislators in Brazil's budgetary process. Comparative Political Studies. Vol 37, № 07, pp.781-815.

PEREIRA, Carlos e MELO, Marcus (2014), Making Brazil work: checking the president in a multiparty system. New York: Palgrave-Macmillan. 236pp.

POGREBINSCHI, Thamy and SANTOS, Fabiano (2011), Participação como representação: o impacto das conferências nacionais de políticas públicas no Congresso Nacional. Dados - Revista de Ciências Sociais. Vol. 54, № 03, pp.259305.

POWER, Timothy (2010), Optimism, pessimism, and coalitional presidentialism: debating the institutional design of Brazilian democracy. Bulletin of Latin American Research. Vol. 29, № 01, pp. 18-33.

SAMUELS, David (2006), Financiamento de campanhas no Brasil e propostas de reforma. In: Reforma política: lições da história recente. Edited by SOARES, Gláucio A. Dillon and RENNÓ, Lucio R.. Rio de Janeiro: FGV Editora. pp. 133156.

SANTOS, Fabiano (2008), Brazilian democracy and the power of 'old' theories of party competition. Brazilian Political Science Review. Vol. 02, pp. 57-76.

SANTOS, Fabiano (2006), Em defesa do presidencialismo de coalizão. In: Reforma política: lições da história recente. Edited by SOARES, Gláucio A. Dillon and RENNÓ, Lucio R.. Rio de Janeiro: FGV Editora. pp. 281-295.

SANTOS, Fabiano (2003), o poder legislativo no presidencialismo de coalizão. Belo Horizonte: Editora UFMG. 257 pp.

SANTOS, Fabiano and ALMEIDA, Acir (2011), Fundamentos informacionais do presidencialismo de coalizão. Rio de Janeiro: Editora Appris. 216pp.

SHUGART, M. S. and CAREY, J. M. (1992), Presidents and assemblies: constitutional design and electoral dynamics. New York: Cambridge University Press. 332pp.

SILVEIRA E SILVA, Rafael (2014), Beyond Brazilian coalitional presidentialism: the appropriation of the legislative agenda. Brazilian Political Science Review. Vol. 08, № 03, pp. 98-135.

SOARES, Gláucio Ary Dillon and RENNÓ, Lucio R. (2006), Projetos de reforma política na Câmara dos Deputados. In: Reforma política: lições da história recente. Edited by SOARES, Gláucio A. Dillon and RENNÓ, Lucio R. Rio de Janeiro: FGV Editora. pp. 09-22.

SOUZA, João Ricardo Carvalho de (2010), The participation of legislative power in Brazilian foreign policy - economy and Mercosur - in the governments of 
Fernando Henrique Cardoso and the first term of Luis Inacio Lula da Silva. $P h D$ Thesis. Rio de Janeiro: IESP-UERJ.

VIEIRA, Fernando Sabóia (2009), Powers and attributions of the president of Senate in the legislative decision-making process. Master's Dissertation. Rio de Janeiro: Iuperj.

WHITEHEAD, Laurence (2009), Fernando Henrique Cardoso: the Astuzia Fortunata of Brazil's sociologist-president. Journal of Politics in Latin America. Vol. 01, № 03, pp. 111-129.

ZUCCO JR., C. (2007), The political economy of ordinary politics in Latin America. Phd dissertation. Los Angeles: University of California. 